\title{
Serious Games Requirements for Higher-Order Thinking Skills in Science Education
}

\author{
Siti Norliza Awang Noh ${ }^{1}$, Nor Azan Mat Zin ${ }^{2}$, Hazura Mohamed ${ }^{3}$ \\ Faculty of Information Science and Technology \\ University Kebangsaan Malaysia, Malaysia \\ 43600 Bangi Selangor, Malaysia
}

\begin{abstract}
Education in the $21^{\text {st }}$ century emphasises the mastery of higher-order thinking skills (HOTS) in the pursuit of developing competitive human capital globally. HOTS can be taught through science education. However, science education is considered very challenging leaving students feeling less interested and less motivated. Apart from that, students are found to be weak in mastering their thinking skills based on the decline in students' achievements in the Trend in International Mathematics and Science Study (TIMSS) and the Programme International Students Assessment (PISA) tests. This situation highlights the need to change the approach of teaching and learning science in line with the current technological changes to meet the challenges of globalisation. Previous studies showed that the use of serious games in learning can enhance students' thinking skills. Thus, serious games can be used to develop higher-order thinking skills among students. This paper presented results of preliminary study using interviews, document analysis, and questionnaire survey. Findings have shown that there are several issues and challenges of teaching and learning in implementing HOTS in science education, in addition to game design requirement for science education. The requirements will be used to design a serious game implementing HOTS in science education.
\end{abstract}

Keywords-Higher-Order Thinking (HOT) skills; educational games; serious games; interface design; science education

\section{INTRODUCTION}

21st-century learning skills require students to have highlevel thinking skills to remain competitive, creative, and innovative. Higher-order thinking skills (HOTS) are defined as the expanded use of the mind to meet new challenges and the process occurs when a person must interpret, analyse or manipulate information because a problem cannot be resolved through the application of previously learned knowledge [1]. Concisely, HOTS is a form of quality thinking that enables one to think more deeply, more productively, and more effectively.

HOTS is a key goal of today's education system worldwide and is also outlined in the country's Education Development Blueprint 2013-2025. An effective method of learning should be implemented to attract students and enhance their HOTS in science. The goal of science education is to help students develop HOTS to meet the challenges of everyday life through enhancing students' cognitive skills such as critical thinking, reasoning, reflective thinking, and science process skills [2].
According to [3] games are a social interaction tool that can stimulate early learning and cognitive development in optimal early childhood education. In addition, play activities bring fun and entertainment as well as encourage individuals to learn something informally. Therefore, the development of computer technology such as serious games can be implemented in the learning process as they offer a strong format for educational environment [4].

Serious games are interactive digital games developed not just for entertainment as the primary purpose but rather as entertainment games that can educate players, also known as educational games. In the field of education, serious games are developed to achieve learning objectives set and are studentoriented. It is in line with the needs of today's students who are born in the age of digital technology known as the Net generation. The Net generation has different skills, interests, and needs, therefore the teaching approach in the education system has to change to meet their requirements. The approaches, methods, techniques, and teaching materials for the current Net generation need to be different from those of the previous generation [5] as the current generation's information processing and thinking are more advanced compared to previous peers. Technology can be used to teach the Net generation.

The biggest challenge of a teacher today is to create an exciting teaching and learning approach to guide students in developing their thinking skills to compete globally. However, the current teaching and learning strategies are exam-oriented that focuses on memorization rather than thinking skills [2]. Lower-order thinking still dominates teaching methods and learning outcomes [6]. Furthermore, the Malaysia Education Blueprint 2013-2025 [7] reported that student encountered difficulty in responding to HOTS exam question in providing complete information along with proof of logic and inability to think critically and logically.

Previous studies discovered that serious games enable the conception of attractive teaching and learning environment, and the development of thinking skills. However, some criteria of the games need to be emphasised so that they are in line with the needs of pedagogy and thinking skills. Balance between the needs of the curriculum and the game structure is important for producing a game that is interesting and does not affect the learning outcomes and functionalities. Apart from that, interesting games often have privileges in terms of accuracy and completeness of learning contents. 
Past studies found plentiful games in the market, but most do not meet the criteria of games for education. This is because game developers only emphasise the gaming aspects rather than learning. According to [8] most private companies have developed digital games without regard to students' learning methods and learning strategies. Besides, games developed for education only cover contents that the developers felt necessary without considering the local education syllabus, which are Standard Based Curriculum for Secondary Schools (KSSM) and Standard Based Curriculum for Primary (KSSR). Hence, our study focused on the requirements of serious game design for HOTS in science education to ensure that educational objectives can be achieved.

This paper discusses the results of preliminary study to identify issues, challenges and requirements for implementing HOTS in science education from educator's perception as well as game design requirements from student's perception. Section II presents a literature review which include theory and related works. Section III describes methods used while Section IV presented result and discussions. The paper concludes with a summary of the study findings and future work.

\section{LITERATURE REVIEW}

\section{A. Higher-Order Thinking Skills in Science Education}

According to [3] Thinking skills are the management of mental processes that occur in the mind or the cognitive system including knowledge, observation, and production. Apart from that, thinking is a mind activity to make decisions in solving problems based on existing information and experiences. Thinking aims to find meaning and understanding of something, explore various ideas or creations and make judgements, and then reflect and be metacognitive about the process. In other words, thinking skills are the ability of an individual to master the potential of his/her mind to control, empower, and adapt to a difficult environment.

According to the definition given in the cognitive domain of Bloom's Taxonomy, there are six cognitive levels of which the first two are known as lower-order thinking skills (LOTS) and the subsequent four levels are higher-order thinking skills (HOTS). LOTS is defined as a simple application and routine steps while HOTS challenges students to interpret, analyse, or manipulate information [9] as shown in Fig. 1.

HOTS is defined by the Curriculum Development Division (2013) of the Ministry of Education Malaysia as the ability to apply knowledge, skills, and values in reasoning and reflection to solve problems, make decisions, innovate, and be creative. According to [11] high-level learning means the capacity to go beyond the information given, to develop critical stance, to have metacognitive awareness, and to solve problems. Thinking critically is thinking at a higher level of cognition that increase the probability of a desirable outcome [12].

The thinking skills elements based on Bloom's Taxonomy consist of knowledge, understand, apply, analysis, synthesis and evaluate. Meanwhile, the elements in Bloom's Taxonomy as reviewed by Anderson and Krathwohl consist of remembering, understanding, applying, analysing, evaluating, and creating. According to the Ministry of Education Malaysia (2013), there are four elements at the highest level outlined in HOTS implementation in schools which are applying, analysing, evaluating, and creating as shown in Table I.

These four elements are important aspects that should be implemented in teaching and learning science to encourage thinking skills among students. However, studies have shown that Malaysian students have moderate level of motivation in science [13]. According to the reports by Trends in International Mathematics and Science Study (TIMSS) in 1999, 2003, 2007, 2011, and 2015, the science scores were declining. Moreover, the Programme for International Student Assessment (PISA) reports also showed similar results in 2009, 2012, and 2015. The deterioration of students' achievements in science subjects at international assessment level reflects that Malaysian students have difficulties in answering HOT-based questions. The application of knowledge according to the four highest levels of cognitive taxonomy does not occur due to most lessons in schools did not sufficiently engage students in constructive thinking[6].

Apart from that, the mastery level of critical thinking and problem-solving skills of science stream students was at a moderate level consistent with the current education that tends to be exam-oriented and fact-based [14], which focused on LOT skill such memorization or "Remember". According to [15] teachers lack knowledge and understanding in methods of teaching for thinking. Moreover, teachers do not know the strategies and methods that can be used to incorporate thinking skills in the teaching and learning process [14]. The teachers are also not familiar with the processes and skills due to their lack of confidence to teach HOTS in science [15].

Higher-Order Thinking Skills

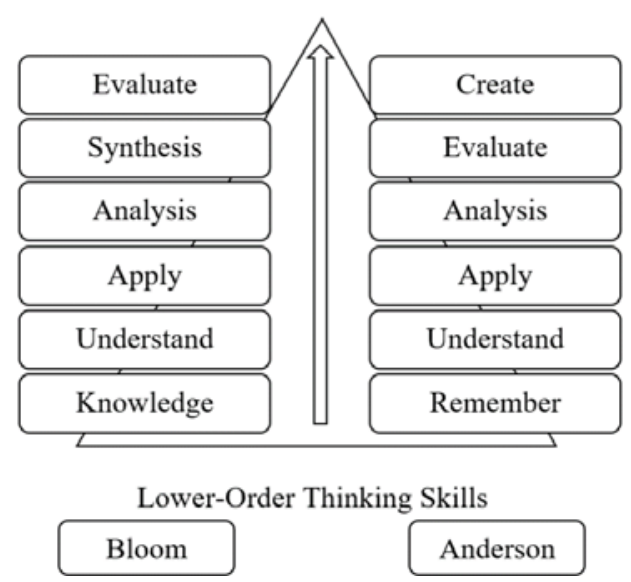

Fig. 1. Reviewed Bloom's Taxonomy (Anderson and Krathwohl, 2001) [10].

TABLE I. HOTS APPLIED IN SCHOOL

\begin{tabular}{|l|l|}
\hline Level of Thinking & Description \\
\hline Create & Use information to create something new \\
\hline Evaluate & Critically examine information and make judgements \\
\hline Analysis & Clarify information and investigate relevance \\
\hline Apply & Use information in new situation (Almost similar) \\
\hline
\end{tabular}


Furthermore, TIMSS 2007 reported science lessons are mostly teacher-centric. In addition Malaysian students were reported watching teachers demonstrate experiments and investigation rather than doing it themselves. TIMSS 2011 also reported that $47 \%$ of Malaysian students were involved in science investigation in less than half of the lessons.

Most students are unable to solve problem-solving questions that require HOTS [16]. This is because understanding science requires students to be able to apply science concepts and principles in solving problems in different situations and contexts. Therefore, scientific inquiries and problem-solving skills need to be cultivated and practised continuously [17].

Serious games are an appropriate learning tool for implementing HOTS in science education as they are not just games involving story, art, and software, but they are a pedagogical activity for educating as well as constructing thinking related to memory skills and learning [18]. Serious games can stimulate learning and cognitive development leading to student-centred learning. In addition, serious games enable educators to attract students' attention and involve them in educational experiences to achieve learning goals [19].

\section{B. Serious Game}

The first concept of serious game was introduced by Clark Abt in 1970, categorised as an entertaining interactive game that allowed players to experience a variety of situations that are impossible to be experienced in the real world [20]. Popular digital games include action games, adventure games, strategy games, and puzzle games.

Serious games are games developed not just for entertainment but also used in business, treatment, medicine, education, health, advertising, and military training. Apart from entertainment, the main purpose of serious games is to train and educate players. One of the most popular serious games is America's Army utilised by the U.S. Army's as a tool in the process of military recruitment and training in the United States. Serious games have also been used in healthcare such as clinical decision-making and patient interaction [21].

Serious games have benefited through interactive learning strategy that provides learning experiences with enjoyment, pleasure, motivation, ego gratification, and emotional change in terms of where, what, and how they learn [22]. Serious games can be considered as a proper educational tool which enhances learning and fulfils students' needs and requirements. According to [21] there is a variety of serious game applications that are applied in computer science, physic, engineering, science, and language learning. Serious games challenge students to think critically in problemsolving.

\section{Serious Game for Education}

Digital games in learning are also known as game-based learning, educational games, and serious games aimed at teaching specific subjects to attract and interest students while providing a fun learning experience. Digital game-based learning is the integration of educational content with computer and video games to engage and motivate beyond leisure activities [21] compared to traditional learning methods. Serious games have been proven to not only attract students to play but also to interest them to interact with the games that create a real learning experience and help them achieve their mission and learning goals of a given subject [23]. According to [20] digital games are very flexible and have the advantages of applying the learning principles and orientations that provide the theoretical foundation as to the efficacy of digital game as a pedagogical tool. One of the most popular games among students today is Minecraft [24]. Previous studies found that Minecraft has benefited students to collaborate as learning progresses.

To implement the use of serious games in education, they must have the advantage of being an interesting, enjoyable[25], motivating, and effective learning tool [26]. Serious games have several advantages in education such as providing a more attractive learning environment for achieving better learning outcomes [27] that can attract students' attention, interest [25], motivation [28] and engage them in educational experiences with a view to achieving specific learning goals and outcomes [25]. Additionally, serious games can increase the efficiency and ability of students [29] and help them understand the content of lessons [30] improve high productivity skills and self-efficacy [31]. Serious games implement the principles of learning by applying various elements as described in the behavioural, cognitive [21], and constructive theories [32]. They also enable development of thinking strategies such as problemsolving, critical thinking, collaborating, creative, automaticity and a host of other higher order thinking skills [25].

The acceptance of digital games by the current net generation is better because they are born in the era of digital technology industry. According to [33] the perception, interest and tendency to video game have a high inclination of children. Furthermore, computer games are today important part of children's leisure and this generation has game-based learning skills [34]. The use of digital games is capable of building the skills required by the net generation, therefore, they should be embedded in school learning. In addition game-based interaction makes their learning more effective [34] and interesting especially among young learner. Furthermore, good serious game design for education has great potential to train or educate students in improving thinking skills which is the main agenda of education in Malaysia in particular. This is because the aspects of digital games involve the selection of strategies and resolution of conflicts as well as problems which are related to one's thinking skills [3]. Playing digital games also embeds critical thinking skills among students to obtain and find solutions in gamified situations.

\section{METHOD}

This study was conducted through semi-structured interview sessions with two School Improvement Specialist Coaches (SISC + ) the officers from the District Education Office (DEO) and eight science teachers to identify the application of the HOTS elements in a science subject. Respondent selections were based on their knowledge and 
experience in implementing HOTS in science. In addition, document analysis was conducted to investigate teachers' knowledge of HOTS and the applicability of this element through documents used by teachers in teaching and learning science. Data from these documents were used to verify the information obtained from the interviews. The documents analysed in this study were the daily lesson plans (DLPs). Further investigation to identify students' expectations of interface game design was conducted involving 60 primary school students using two educational games - Electric Circuit and Learning Circuit. The features for interface game design identified from previous studies were used in a questionnaire.

\section{RESULTS AND DisCUSSION}

\section{A. Interview}

Based on the interviews conducted, the teachers reported that students had difficulties understanding the concepts of science due to several factors. One of the main factors is that science education is said to be abstract, indirectly affecting the attitude of students in science education. The implications of this situation have left students feeling less interested, less motivated, anxious, and worried about the science subject. This situation has led to a decline in students' achievement in science.

Moreover, the elements of HOTS are difficult to be implemented in science teaching and learning. Although the learning approach used is student-centred, the students are still exposed to memorisation and exam-oriented techniques. Teaching and learning activities are limited to the classroom setting only which cause students to not remember the things they have learned. However, students like to perform experiments, but they still do not understand the related science concepts. They are finding it difficult relating HOTS in science to daily life. HOTS situation experienced at home cannot be applied when visualised in the form of a question. This situation leads to the weakness in the aspect of students' thinking skills as they are less trained to think broadly and critically.

The study has also found that teachers' knowledge of HOTS are still low as some of them could not explain all the HOTS elements. Despite the exposure to the HOTS elements of teaching, it is evident that teachers are still unclear about the use of the elements in teaching and learning. The findings also showed that teachers are not sure of the strategies and methods to incorporate thinking skills and how to train students for HOTS. Additionally, teachers are bound by the school schedule and still tied to the syllabus provided in the textbook.

Currently, HOTS implementation in teaching and learning can also be applied using technology tools. However, interviews with SISC+ officers found that developers of educational digital games only cover contents that they felt necessary without considering the local syllabus and do not implement all HOTS elements. Moreover, existing games do not encourage users to think and do not generate inference skills. The finding is supported by previous study [8] which existing digital games are developed without considering students' learning styles, differentiation, and learning strategies. Table II summarises some of the most significant findings derived from the preliminary study related to the issues, challenges, and requirements in teaching HOTS in science from educators' perception.

TABLE II. ThE ISSUES, CHALLENGES, AND REQUIREMENTS IN TEACHING HOTS IN SCIENCE EDUCATION FROM EDUCATORS’ PERCEPTION

\begin{tabular}{|c|c|c|}
\hline Category & Issues / Challenges & Requirements \\
\hline $\begin{array}{l}\text { Student } \\
\text { attitude }\end{array}$ & $\begin{array}{l}\text { 1. Less interested in science } \\
\text { 2. Less motivated in science } \\
\text { 3. Have anxiety of science } \\
\text { 4. Low achievement in } \\
\text { science }\end{array}$ & 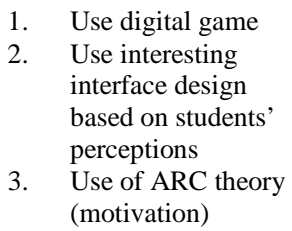 \\
\hline $\begin{array}{l}\text { HOTS in } \\
\text { Science }\end{array}$ & $\begin{array}{l}\text { 1. Student cannot answer the } \\
\text { 2. } \begin{array}{l}\text { HOTS questions } \\
\text { Difficult to understand the } \\
\text { concept of HOTS in } \\
\text { Science } \\
\text { 3. The HOTS situation } \\
\text { experienced at home } \\
\text { cannot be applied when } \\
\text { visualised in the form of } \\
\text { question. } \\
\text { 4. Students are not able to } \\
\text { retain in memory the } \\
\text { things they have learned } \\
\text { 5. } \begin{array}{l}\text { Students like to perform } \\
\text { experiment, but still do }\end{array} \\
\text { not understand the related } \\
\text { science concepts. }\end{array} \\
\text { 6. } \begin{array}{l}\text { Difficulty relating science } \\
\text { to daily life. }\end{array}\end{array}$ & $\begin{array}{l}\text { Implementing HOTS in } \\
\text { game designs through } \\
\text { tasks/challenges }\end{array}$ \\
\hline $\begin{array}{l}\text { Teaching } \\
\text { strategy }\end{array}$ & $\begin{array}{l}\text { 1. Teaching students skill to } \\
\text { answer exam questions } \\
\text { only (low thinking skill) } \\
\text { 2. Teachers' knowledge of } \\
\text { HOTS are still low } \\
\text { 3. Teachers are not sure the } \\
\text { strategies and methods } \\
\text { that can be used to } \\
\text { incorporate thinking skills } \\
\text { and how to train students } \\
\text { for HOTS. }\end{array}$ & $\begin{array}{l}\text { Designing HOTS in } \\
\text { context of Science } \\
\text { subject }\end{array}$ \\
\hline $\begin{array}{l}\text { Technology } \\
\text { approaches }\end{array}$ & $\begin{array}{l}\text { 1. } \begin{array}{l}\text { Technology tools being } \\
\text { used in teaching and } \\
\text { learning such as } \\
\text { Courseware, Video, } \\
\text { Audio, Internet, } \\
\text { Simulation, and Game } \\
\text { digital }\end{array} \\
\text { 2. } \quad \begin{array}{l}\text { Existing contents that } \\
\text { developer felt necessary } \\
\text { without considering the } \\
\text { local syllabus. }\end{array} \\
\text { 3. } \quad \begin{array}{l}\text { Existing games do not } \\
\text { encourage users to think }\end{array} \\
\text { 4. } \quad \begin{array}{l}\text { Not all HOTS elements } \\
\text { are implemented in the } \\
\text { existing games }\end{array} \\
\text { The content of existing } \\
\text { games do not relate with } \\
\text { real life situations } \\
\text { 6. } \begin{array}{l}\text { Existing games do not } \\
\text { generate inference skills }\end{array}\end{array}$ & 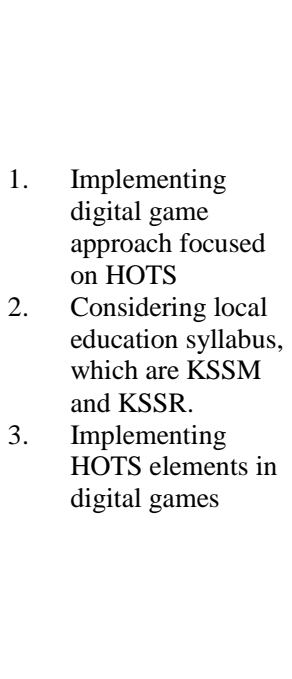 \\
\hline
\end{tabular}




\section{B. Document Analysis}

The results of the document analysis show that teachers did not specify the HOTS elements planned in writing in their daily lesson plans. Students were not trained to perform highlevel thinking during teaching and learning. The teaching and learning methods such as experiments are still tied to the syllabus provided in the textbook. The findings have also shown that the teachers did not use varied teaching aids to implement the HOTS elements. The teachers only used textbooks and no teaching aids. In conclusion, teachers still have difficulties in implementing HOTS in teaching and learning. Furthermore, the implementation of all HOTS elements is not yet done in the teaching and learning of science.

\section{Questionnaire}

Studies showed that the students have very high interests in using digital games for learning purposes [4]. However, there are some requirements for more interactive learning experiences in digital games based on students' expectations.

The results show that students rating is less than 3.0 (mean score) for the interface game design elements, text, image, audio, and animation. These are important elements to attract students to play games while learning science. Based on these games, the students reported that they find it difficult to understand the language, terms and the meaning of the sentences. The language used does not match their age although the role of language is important to understand the content of the game. Therefore, the use of familiar language and the means of delivering information in the form of sentences should be concise to facilitate students' understanding of the game's content.

Additionally, these games have shown the use of unrelated and uninteresting images for science learning, indirectly making it difficult for students to grasp the content. Science is a subject that involves real-life environment, therefore, the animated images in games need to be interesting and relatable to real situations that link science to everyday life.

The use of unattractive audio has also bored the students. This shows that the use of audio is important to attract students in this age group to play the game. Therefore, using interesting and appropriate background music and sound effects related to the realistic story, environment, character, component and movements for science learning are important so that students do not get bored but are more excited to play while learning.

Moreover, the use of uninteresting animations has left students bored and less interested in the game. The use of interesting and compatible animations in term of story, environment, character, component and movements that relate to the real situation for science learning are important for engaging students at play and at the same time learning science.

The findings have shown that even though these games are developed for learning science, the requirements of the games selected must be aligned with users' expectations of interface game design. It is important to attract students' interest to play and enhance their motivation and thinking skills in science by using digital games. Table III shows results of the students' game requirement survey.
TABLE III. THE GAME DESIGN REQUIREMENTS FROM STUDENT’S PERCEPTION

\begin{tabular}{|l|l|l|}
\hline \multirow{2}{*}{ Requirement } & Mean \\
\cline { 2 - 3 } & $\begin{array}{l}\text { Electric } \\
\text { Circuit }\end{array}$ & $\begin{array}{l}\text { Learning } \\
\text { Circuit }\end{array}$ \\
\hline The use of word is easy to understand & 2.9 & 2.9 \\
\hline $\begin{array}{l}\text { The use of language is easy to understand } \\
\text { science learning }\end{array}$ & 2.35 & 2.65 \\
\hline $\begin{array}{l}\text { The meaning of the sentence is easy to } \\
\text { understand science learning }\end{array}$ & 2.35 & 2.65 \\
\hline The use of images are related to science learning & 2.98 & 2.95 \\
\hline $\begin{array}{l}\text { The use of background music for science } \\
\text { learning is interesting }\end{array}$ & 2.3 & 1.56 \\
\hline $\begin{array}{l}\text { The use of sound effects is suitable for science } \\
\text { learning }\end{array}$ & 1.56 & 1.96 \\
\hline $\begin{array}{l}\text { The use of animation for science learning is } \\
\text { interesting }\end{array}$ & 2.7 & 1.81 \\
\hline $\begin{array}{l}\text { The use of animation is appropriate } \\
\text { (compatible) with science learning }\end{array}$ & 2.98 & 2.9 \\
\hline
\end{tabular}

\section{CONCLUSION}

HOTS elements are essential requirements to train students for higher thinking skills to meet the challenges of the future. Teaching and learning using serious games can encourage thought processes while playing. The requirements gathered from this study will be used to design a serious game to teach science. For future work will involve designing a serious game for teaching.

\section{ACKNOWLEDGMENT}

The authors acknowledge the help given by the Sekolah Kebangsaan Sultan Ibrahim Dua, Sekolah Kebangsaan Dato Hamid Satu, Sepang District Education Office and Pasir Mas District Education Office. We also thank the Malaysian Ministry of Education for funding the under program MyBrain15 (MyPhD) and UKM Publication sponsorship under the grant PP-FTSM-2020.

\section{REFERENCES}

[1] R. Nagappan, Teaching and Acquiring Higher-Order Thinking Skills Theory and Practice. Penerbitan Universti Pendidikan Sultan Idris, 2016.

[2] N. A. N. Y. Mohd Nazri Hassan, Ramlee Mustapha, Rosnidar Mansor, "Pembangunan Modul Kemahiran Berfikir Aras Tinggi di dalam Mata Pelajaran Sains Sekolah Rendah: Analisis Keperluan Guru,” Sains Humanika, vol. 9, no. 1-5, pp. 119-125, 2017.

[3] M. Noor, B. Madjapuni, and J. Harun, "Kemahiran Berfikir Kritis melalui Permainan Digital Dalam Persekitaran Kemahiran Berfikir Kritis melalui Permainan Digital Dalam Persekitaran Pembelajaran Konstruktivisme Sosial,” no. January, 2019.

[4] H. Supeno, M. Liyanthy, and E. H. N. Huda, "Game development to train critical thinking in science subjects using model of digital game based learning-instructional design,” Int. J. Innov. Technol. Explor. Eng., vol. 8, no. 8, pp. 192-195, 2019.

[5] M. N. Masran, L. F. Md Ibharim, and M. H. Mohamad Yatim, "Pendekatan Pembelajaran Melalui Reka Bentuk Permainan Digital dalam Proses Pengajaran dan Pembelajaran Kanak-kanak: Isu dan Cabaran,” Pendekatan Pembelajaran Melalui Reka Bentuk Permainan Digit. dalam Proses Pengajaran dan Pembelajaran Kanak-kanak Isu dan Cabaran, no. October, pp. 1-10, 2014. 
[6] S. Y. Tan and S. H. Halili, "Effective Teaching of Higher-Order Thinking (HOT) in Education," Online J. Distance Educ. e-Learning, vol. 3, no. 2, pp. 41-47, 2015.

[7] Ministry of Education Malaysia, "Malaysia Education Blueprint 2013 2025,” Education, vol. 27, no. 1, pp. 1-268, 2013.

[8] A. Koptelov and S. Taube, "Learning Mathematics and Critical Thinking via Computer Games Design,” J. Math. Sci., vol. 2, pp. 88-96, 2015.

[9] Y. Abosalem, "Assessment techniques and students' higher-order thinking skills,” ICSIT 2018 - 9th Int. Conf. Soc. Inf. Technol. Proc., no. March, pp. 61-66, 2016.

[10] D. Scully, "Constructing Multiple-Choice Items to Measure HigherOrder Constructing Multiple-Choice Items to Measure Higher-Order Thinking,” Pract. Assessment, Res. Eval., vol. 22, 2017.

[11] A. Endah Retnowati, Anik Ghufron, Marzuki, Kaisyan, Adi Cilik Pierawan, Character Education for 21st Century Global Citizen. Routledge, 2018, 2018.

[12] O. May, O. May, and K. Kamp, "Metacognitive Awareness and Critical Thinking Abilities of Pre-service EFL Teachers,” J. Educ. Learn., vol. 7, no. 5, pp. 116-129, 2018.

[13] C. H. Norlizah, "Students ' Motivation towards Science Learning and Students ' S cience Achievement,” Int. J. Acad. Res. Progress. Educ. Dev., vol. 6, no. 4, pp. 174-189, 2017.

[14] M. N. Hassan, R. Mustapha, N. A. Nik Yusuff, and R. Mansor, "Pembangunan Modul Kemahiran Berfikir Aras Tinggi di dalam Mata Pelajaran Sains Sekolah Rendah: Analisis Keperluan Guru,” Sains Humanika, vol. 9, no. 1-5, 2017.

[15] W. Mazwati, W. Yusoff, S. C. Seman, W. Mazwati, and W. Yusoff, "Teachers ' Knowledge of Higher Order Thinking and Questioning Skills : A Case Study at a Primary School in Teachers' Knowledge of Higher Order Thinking and Questioning Skills: A Case Study at a Primary School in Terengganu , Malaysia,” Int. J. Acad. Res. Progress. Educ. Dev., vol. 7, no. 2, pp. 45-63, 2018.

[16] S. Nur, D. Mahmud, N. M. Nasri, M. A. Samsudin, and L. Halim, "Science teacher education in Malaysia: challenges and way forward," Asia-Pacific Sci. Educ., pp. 0-11, 2018.

[17] M.-T. Cheng, J.-H. Chen, S.-J. Chu, and S.-Y. Chen, "The use of serious games in science education: a review of selected empirical research from 2002 to 2013,” J. Comput. Educ., vol. 2, no. 3, pp. 353-375, 2015.

[18] P. E. Turner, E. Johnston, M. Kebritchi, S. Evans, and D. A. Heflich, "Influence of online computer games on the academic achievement of nontraditional undergraduate students," Cogent Educ., vol. 42, no. 1, pp. 1-16, 2018.

[19] W. Westera, "Why and How Serious Games can Become Far More Effective: Accommodating Productive Learning Experiences, Learner Motivation and the Monitoring of Learning Gains,” Int. Forum Educ. Technol. Soc., vol. 22, no. 1, pp. 59-69, 2019.

[20] K. Madani, T. W. Pierce, and A. Mirchi, "Serious Games on Environmental Management," pp. 1-44, 2007.
[21] D. Vlachopoulos and A. Makri, "The effect of games and simulations on higher education : a systematic literature review," Int. J. Educ. Technol. High. Educ., pp. 1-33, 2017.

[22] A. S. Drigas, "Serious Games in Preschool and Primary Education: Benefits And Impacts on Curriculum Course Syllabus Serious Games in Preschool and Primary Education : Benefits And Impacts on Curriculum Course Syllabus,” Int. J. Emerg. Technol. Learn., no. January, 2017.

[23] R. Hodhod, H. Fleenor, and S. Nabi, "Adaptive Augmented Reality Serious Game to Foster Problem Solving Skills,” Work. Proc. 10Th Int. Conf. Intell. Environ., no. January, pp. 273-284, 2014.

[24] M. Pusey and G. Pusey, "Using Minecraft in the Science Classroom," Int. J. Innov. Sci. Math. Educ., vol. 23, no. 3, pp. 22-34, 2015.

[25] T. Anastasiadis, G. Lampropoulos, and K. Siakas, "Digital Game-based Learning and Serious Games in Education,” Int. J. Adv. Sci. Res. Eng., vol. 4, no. 12, pp. 139-144, 2018.

[26] Noor Azli Mohamed Masrop et al., "Kesan Permainan Digital Dalam Pendidikan,” Proceeding Int. Conf. Inf. Technol. Soc. 2015), vol. 2003, no. June, pp. 1-7, 2015.

[27] P. Lameras, S. Arnab, I. Dunwell, C. Stewart, S. Clarke, and P. Petridis, "Essential Features of Serious Games Design in Higher Education: Linking Learning Attributes to Game Mechanics,” Br. J. Educ. Technol., vol. 48, no. 4, pp. 972-994, 2017.

[28] Mercy Trinovianti Mulyadi and N. A. M. Zin, "MMORPG Game Framework Based on Learning Style for Learning Computer Networking,” Asia-Pacific J. Inf. Technol. Multimed., vol. 8, no. 1, pp. 63-77, 2019

[29] K. Nisa, C. Z. Zulkifli, N. A. A. Aziz, and N. M. Nordin, "Reka bentuk gamifikasi pembelajaran geografi berasaskan Permainan Geoplay," Geografi, vol. 5, no. 1, pp. 46-61, 2017.

[30] K. Fu, T. Hainey, and G. Baxter, "A Systematic Literature Review to Identify Empirical Evidence on The Use of Computer Games in Business Education and Training,” 10th Eur. Conf. Games Based Learn., vol. 1, pp. 232-239, 2016.

[31] K. O. Ah-Nam Lay, "Developing 21 st Century Chemistry Learning through Designing Digital To cite this article : Developing 21 st Century Chemistry Learning through Designing Digital Games,” J. Educ. Sci. Environ. Heal., vol. 4, no. 1, pp. 81-92, 2018.

[32] L. Ah-nam and K. Osman, "Developing 21 st Century Skills through a Constructivist-Constructionist Learning Environment,” K-12 STEM Educ., vol. 3, no. 2, pp. 205-216, 2017.

[33] R. Aziz, H. Norman, N. Nordin, F. N. Wahid, and N. A. Tahir, "They Like to Play Games? Student Interest of Serious Game-Based Assessments for Language Literacy,” Creat. Educ. ERA;, pp. 31753185, 2019.

[34] R. D. Agustin, "Serious Games for Effective Learning," 2017 6th Int. Conf. Electr. Eng. Informatics, 2017. 